\title{
The Causes of Poor Performance in English Language among Senior Secondary School Students in Dutse Metropolis of Jigawa State, Nigeria
}

\author{
${ }^{1}$ Tata Umar Sa'ad, ${ }^{2}$ Rabiu Usman \\ ${ }^{I}$ NCE, B.Ed and M.Ed (Sociology of Education) Senior Lecturer \\ Foundations Department, College of Education, Azare Bauchi State, Nigeria \\ And \\ ${ }^{2}$ B. A. Ed (Hausa) Hausa Department, College of Education, Azare Bauchi State, Nigeria
}

\begin{abstract}
The study investigated the causes of poor performance in English language among secondary school students in Dutse metropolis of Jigawa state. Responses were elicited from students and teachers in five secondary schools in Dutse metropolis. The study sample was 379, in which 300 were students and 79 were teachers. The descriptive survey design was used and questionnaire was used in collection of data. Frequency and simple percentage were used in the analysis of data. The findings of the study led to the conclusion that the dominance of mother tongue, inadequate qualified teachers of English language, negative attitudes of students toward English language, improper use of method in teaching English language, inadequate instructional media and facilities, lack of language laboratory for teaching English language are the causes of poor performance in English language among secondary school students of Dutse metropolis of Jigawa state.. The study also found out that provision of qualified teachers of English language, using the right approach to teaching of English language, provision of language laboratory, engaging of students in debating and listening to English programmes are some of the ways that can improve secondary school students' performance in English language. The study also recommended that qualified teachers of English language should always be employed to teach it, adequate facilities and instructional media/materials need to be provided and where they are not available teacher are to improvise, proper supervision by all stakeholders should be imbibed and so on.
\end{abstract}

Key words: Poor Performance, English Language, Secondary Schools Students, Dutse Metropolis

\section{Introduction}

English Language is the instrument of communication in our post primary institutions, higher institutions as well as the official language of the country. Therefore, secondary school students need effective English language to function properly or perform better. Fema, (2003) was of the view that "a person is functionally literate when he acquired the knowledge and skills in reading and writing which enables him to engage effectively in all those activities in which literacy is normally assumed in his culture of group". English language normally has four basic skills, namely listening, speaking, reading and writing. It is the medium of instruction in our schools and compulsory school subject that must be passed at all levels of education in Nigeria (Danladi, 2008).

However, it is disheartening to note that the poor performance of students in English language at public examinations in recent times has been explained as a major cause of decline in the general academic performance and standard of education in Nigeria. Oluwole, (2008) was of the view that "having difficulty in grasping fully the contents and concepts of the various subjects of the curriculum taught in target language seem to be one of the most serious problems that English as a first language students face in their particular course of study. This might be due to their weaknesses in English language (the medium of instruction) which may have negative consequences on their overall performance.

The Daily Trust of Wednesday, August 25, 2010 reported that "seventy-five per cent of candidates who sat for May/June WAEC 2010 examinations failed to meet the minimum entry requirement into tertiary institutions. The recently released WAEC results indicated that over seventy percent fail in November/December results. 86,612 candidates, representing 29.17 percent of the total number of candidates who sat for the NOV/DEC examinations of West African Examination Council (WAEC), obtained credits in five subjects and above, including English language and Mathematics. Again, the WAEC has released its May/June 2014 WASSCE results, recording mass failure in mathematics and English language. Head of National Office, WAEC Charles Eguridu, while announcing the results said "A total of 529,425 candidates; representing 31.28 percent obtained credits. According to him when compared to the 2012 and $2013 \mathrm{May} / \mathrm{June}$ WASSCE, there was marginal decline in the performance of candidates as 38.81 percent was recorded in 2012 and 36.57 in 2013. 
Figure1: A bar chart showing WAEC percentage results of students who made five credits and above including Mathematics and English from 2009 to 2014.

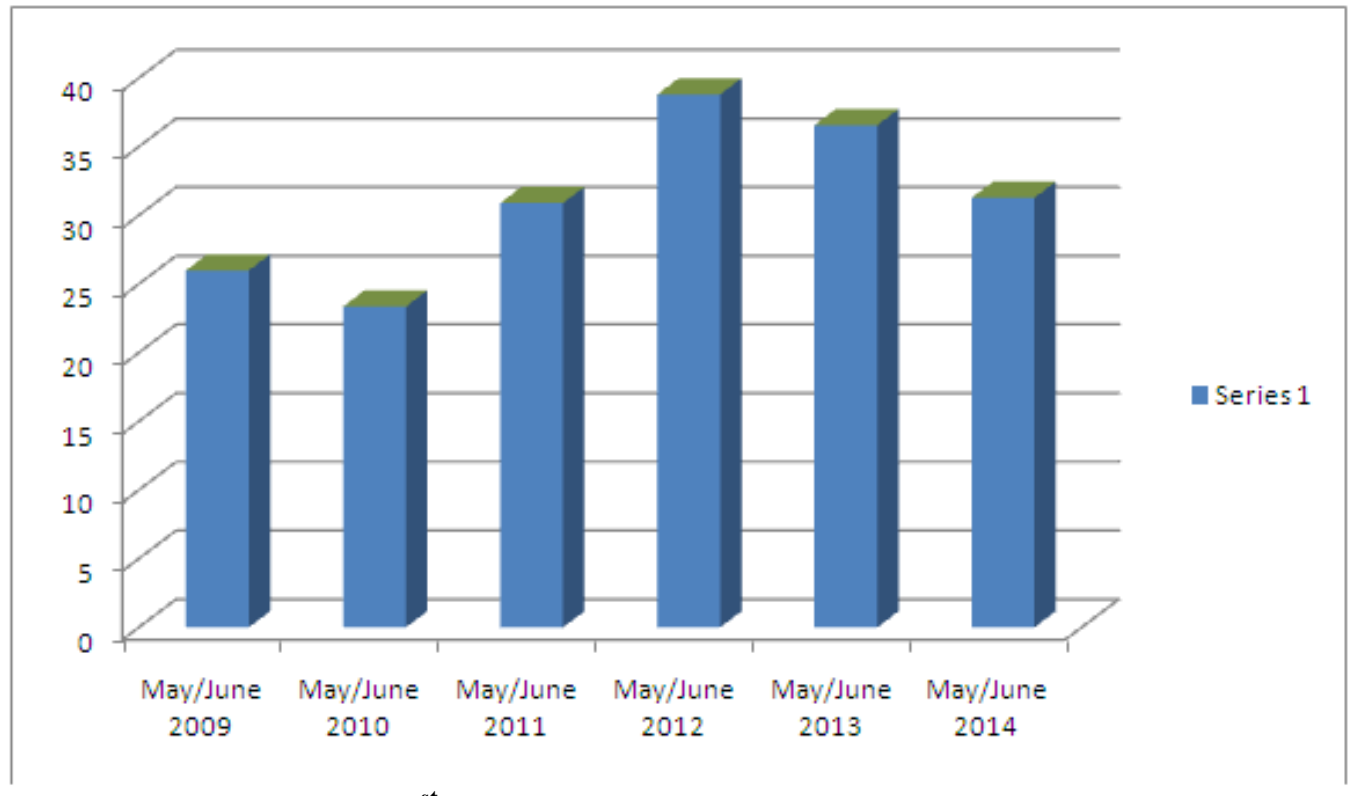

Source: Daily Trust of Thursday $21^{\text {st }}$ August, 2014

In the bar chart above, in 2009 only $25.99 \%$ made five credits and above including mathematics and English but in 2010 there was a decline to $23.36 \%$. In 2011 the percentage pass of students in WAEC rose to $30.9 \%$ and fortunately continued to rise to $38.81 \%$ in 2012 . However, in 2013 the performance declined to $36.57 \%$, and unfortunately continued to decline to $31.28 \%$ in 2014 .

Therefore, it is against this background that this study investigates into the causes of poor performance in English language among secondary school students in Dutse metropolis of Jigawa state.

\section{Review of Related Literature}

There are many causes of poor performance in English language among senior secondary school students. These include the followings:

The dominance of mother tongue is regarded as one of the cause of poor performance in English language. Usman, (2012) was of the view that Nigerian students are surrounded by a complex linguistic situation that force them to learn their first indigenous language and they are required to have a good command of the English language. The Nigerian policy on education stressed the use of the immediate language of the community in instruction at the lower level of primary education and combination of English and language of the immediate community at the upper part of primary education. In other words, the policy recommended the use of mother tongue in teaching at primary level. This situation contributes immensely in poor learning of English language right from primary school and it extends to secondary school. Fema, (2003) was of the view that the major cause of the errors in English used by Nigerians can be attributed to the interference of mother tongue with the English language. He added that students often use their native language or mother tongue in all their interactions and English is only used within the four walls of the classrooms and ends there.

The above situation clearly shows that dominance of mother tongue in Azare metropolis contributed immensely in poor performance in English language.

Inadequate qualified English language teachers also cause poor performance in English language in our secondary schools. Due to the above mentioned cause, in some schools other subject teachers are forced to teach English language and some who even read it exhibit poor abilities in oral and written expression of it. Therefore, with this kind of situation these teachers can never teach effectively and hence poor performances from their products. Adedokun, (2011) was of the view that poorly trained English and untrained teachers (of English) were employed to teach and prepare secondary school students for the school certificate examinations in English language. This situation contributed immensely in poor performance in English language among secondary school students.

Therefore, is clear to us that inadequate qualified teachers in our secondary schools lead to poor performance in English language.

Inadequate Infrastructural Facilities and Instructional Media are regarded as another cause of poor performance in English language in our secondary schools. Roger, (1981) was of the view that instructional materials and facilities are important part of the process of learning as they provide practice and feedback in 
learning track. In our present day secondary schools particularly public ones students are in most cases sitting on the floor and windows during lessons. In some cases students are living under trees or living in dilapidated classroom. In addition to that even where there are enough classes, they are overcrowded and language laboratories are lacking. All these cannot allow for proper learning of English language and other subjects hence lead to poor performance. Sa'ad (2007) was of the view that teaching and learning take place effectively when classes are moderate. But the present day Nigerian class is over populated with students over 120 and this cannot allow for proper teaching and learning. On the other hand, in the area of instructional resources or media, there is dominance of textbooks, dictionaries, workbooks and posters in the teaching of English language in secondary schools in Nigeria. Modern media such as audio, video tapes, language laboratories, programmed texts, flash cards; computers, magazines and newspapers are rarely used. Mohammed, (1998) observed that the teaching of English language is bedeviled with many problems such as inadequate period of teaching, method of teaching and lack of adequate and useful resources.

Therefore, it is clear to us that inadequate infrastructural facilities leading to large class sizes and inadequate as well as obsolete teaching resources or media lead to poor performance in English language in our secondary schools.

Another important cause of poor performance of English language in Nigerian secondary schools is the teachers' attitude toward innovation and use of instructional media. Most Nigerian secondary school English language teachers fail to take into account the dynamic nature of English curriculum but they continued to bore students with definitions and drills in grammer, vocabulary and speech work. The traditional content/knowledge oriented teaching is still very much practiced by them. Abdullahi, (2003) was of the view that teachers mostly prefer to use traditional ways of teaching which they have been familiar with or as they were taught, which do not necessarily aid proper learning. Ya'u, (1993) categorically said that successful achievement of stated objectives in teaching and learning is always associated with using the right technique.

Therefore, it is clear to us that poor attitude of teachers toward innovation and use of instructional media or materials in teaching English language leads to poor performance among secondary schools in Azare metropolis.

Another important cause of poor performance in English language is the negative attitude of students toward the learning of English language. Students, particularly in secondary and primary schools mostly show negative attitude toward learning of English language because they consider it foreign or not theirs. Mohammed, (2002) was of the view that most students put a kind of negative attitude in learning and use of English language as well as making teachers task a difficult one in deed. It is obvious that for any student to be proficient in English language, mastering of skill of listening, speaking, reading and writing is necessary, and it requires a hardworking and dedication from the students.

Therefore, it is clear that the negative attitude of students toward learning of English language is one of the causes of poor performance in the subject (English language).

Improper use of method of teaching also causes poor performance in English language among secondary school students. It is obvious that successful teaching and learning take place when right teaching methods are used by the teachers. Ya'u, (1993) in Sa'ad, (2007) was of the view that successful achievement of stated objectives in teaching and learning is always associated with using the right method. Sometimes teachers of English language do not consider the learners' age, the topic, the time and background of the learners in choosing the method to be used in teaching and this affects the level of learning of the students.

Therefore, it is clear that teachers' inability to use proper teaching methods contributes in poor learning of English language among secondary school students.

There are many ways that can be followed to improve the English language performance of secondary school students. These are:

Abdullahi, (2003), Sa'ad, (2007), Abdulganiyu, (2010) and Usman, (2012) were of the view that provision of enough instructional media/materials, qualified teachers as well as conducive classrooms will assist a lot in improving the performance of secondary school students in English language.

Udumah, (1987) was of the view that teachers should device ways through which they can help the students to improve their learning, speech and their listening skills. He categorically stated that:

> Students should be taught correct pronunciation in English language in order to minimize the effect of the first language on the second (English language).

$>$ Instructional materials and facilities should be provided for effective teaching and learning of English language.

$>$ More qualified teachers of English language should be provided and they should be encouraged to undergo professional teaching courses, workshops and seminars to update them.

$>$ Students should be encouraged to communicate in English language in and outside the classroom.

- Facilities like language laboratory should be provided to assists in proper teaching and learning of English language. 
Objective of the study

The main objectives of this study are to:

i. Find out the main causes of poor performance in English language among secondary school students in Dutse Metropolis of Jigawa state.

ii. Find out the ways of improving learning of English language among secondary school students in Dutse Metropolis of Jigawa state.

\section{Research Design}

The design that was used in this study was descriptive survey. It was used because it permitted the researchers to study small sample and later generalized the findings to the whole population. Osuala, (2001) was of the view that in survey research small sample is studied and the findings generalized to the population.

\section{Research Questions}

This study attempted to provide answers to the following question:

1. What are the main causes of poor performance in English language among senior secondary school students in Azare metropolis?

2. What are the ways of improving learning of English language among senior secondary school students of Dutse Metropolis of Jigawa state?

\section{Population of the study}

The population of this study was twenty-nine thousand, eight hundred and seventy-four, in which twenty-nine thousand, five hundred and seventy-two were students and three hundred and two were teachers.

\section{Sample for the study}

The sample used in this study was three hundred and seventy-nine students and teachers selected using stratified random sampling technique, in which three hundred students and seventy-nine teachers were selected. The sample was selected based on Krejcie and Morgan's table of sample as contained in Kolo, (1992).

\section{Sampling Technique}

Stratified random sampling technique was used in selecting the sample for this study. This is because it permitted the researcher to have representation from both the teachers and the students.

\section{Instrument for Data collection}

A questionnaire was used as an instrument for the collection of data for this study. The questionnaire comprises of twelve items on the variables of the study. The response format of "Yes" or "No" was used in the instrument.

\section{Validity and Reliability of the Instrument}

The instrument was validated by experts who have more than two decades of teaching research methods in College of Education, Azare.

The reliability of the instrument was determined by using test-retest method. The instrument was used on twenty members of the population and after ten days the same instrument was used on the same members. The two results were correlated using Pearson product moment correlation coefficient and the result got was 7.0. This makes the instrument reliable.

Data Analysis Procedure

The data collected was analyzed using frequency and simple percentage.

\section{Data Presentation and Analysis of Results}

This section focuses on presentation and analysis of the data collected from the respondents as well as the discussion of results.

Research Question 1: What are the main causes of poor performance in English language among senior secondary school students in Dutse metropolis of Jigawa state? 
Table 1: Showing responses obtained from Research Question one.

\begin{tabular}{llll}
\hline S/NO. & QUESTION & YES/\% & NO/\% \\
\hline 1. & $\begin{array}{l}\text { Do you prefer to speak English language than your mother- } \\
\text { tongue at school? }\end{array}$ & $32(19 \%)$ & $307(81 \%)$ \\
2. & $\begin{array}{l}\text { Does mother-tongue cause problem to you in learning English } \\
\text { language? }\end{array}$ & $361(95 \%)$ & $18(5 \%)$ \\
3. & $\begin{array}{l}\text { Are there available instructional media/materials and facilities } \\
\text { for teaching English language in your school? }\end{array}$ & $50(13 \%)$ & $329(87 \%)$ \\
4. & $\begin{array}{l}\text { Are there available qualified English language teachers in your } \\
\text { school? }\end{array}$ & $30(8 \%)$ & $349(92 \%)$ \\
5. & $\begin{array}{l}\text { Are proper teaching methods used in teaching English } \\
\text { language in your school? }\end{array}$ & $37(20 \%)$ & $302(80 \%)$ \\
6. & $\begin{array}{l}\text { Is there language laboratory for teaching English language in } \\
\text { your school? }\end{array}$ & $5(0 \%)$ & $379(100 \%)$ \\
\end{tabular}

Source: Field work, 2014

In table 1 above, 72 respondents representing 19\% prefer speaking English language than English language while in school. But 307 representing $81 \%$ prefer speaking their mother-tongue and other local languages than English language. However, 361 respondents representing 95\% were of the view that mother tongue causes problem to them in learning English language while 18 respondents representing 5\% were against this view. About 50 respondents representing 13\% were of the view that there were instructional media and facilities in their schools while 321 respondents representing $87 \%$ were saying that there were no instructional media and facilities in their school. Only 30 respondents representing $8 \%$ said that they have qualified teachers of English language in their schools while 349 representing 92\% were saying that there were no enough qualified teachers of English language in their schools. Only 77 respondents representing 20\% said that teachers used proper methods of teaching in the discharge of their responsibilities as teachers of English language while 302 respondents representing $80 \%$ said that the teachers of English language do not used proper or appropriate methods in teaching English language in their schools. Finally, all the respondents said that there was no single language laboratory in all the schools in Dutse Metropolis of Jigawa state.

Therefore, it is clear to us that the main causes of poor performance in English language among the students of secondary schools in Dutse metropolis of Jigawa state include students' lack of interest in speaking English, dominance of mother tongue even in schools, insufficient instructional media and facilities, using of improper methods in teaching English language and lack of language laboratory in all the secondary schools in Dutse metropolis.

Research Question 2: What are the ways of improving learning of English language among senior secondary school students of Dutse Metropolis of Jigawa state?

Table 2: Showing the responses on Research Question two.

\begin{tabular}{|c|c|c|c|}
\hline S/NO. & QUESTION & YES/\% & $\mathrm{NO} / \%$ \\
\hline 1. & $\begin{array}{l}\text { Do provision and appropriate use of instructional media as } \\
\text { well as facilities improve learning of English language in your } \\
\text { school? }\end{array}$ & $369(97 \%)$ & $10(3 \%)$ \\
\hline 2. & $\begin{array}{l}\text { Can employment of qualified teachers of English language } \\
\text { improve learning of it in your school? }\end{array}$ & $379(100 \%)$ & $00(0 \%)$ \\
\hline 3. & $\begin{array}{l}\text { Do you think the use of proper method of teaching by the } \\
\text { teachers can improve learning of English language in your } \\
\text { school? }\end{array}$ & $379(100 \%)$ & $00(0 \%)$ \\
\hline 4. & $\begin{array}{l}\text { Do you think provision of language laboratory can improve the } \\
\text { learning of English language in your school? }\end{array}$ & $309(82 \%)$ & $70(18 \%)$ \\
\hline 5. & $\begin{array}{l}\text { Do you think listening to any English programme by the } \\
\text { students can improve their learning of English language in } \\
\text { your school? }\end{array}$ & $355(94 \%)$ & $24(6 \%)$ \\
\hline 6. & $\begin{array}{l}\text { Do you think organizing debates in your school can improve } \\
\text { the learning and performance of students in English language? }\end{array}$ & $304(80 \%)$ & $75(20 \%)$ \\
\hline
\end{tabular}

\section{Source: Field work, 2014}

In table 2 above, 369 respondents representing $97 \%$ were of the view that provision and appropriate use of instructional media can improve the teaching and learning as well as the performance of secondary school students in English language in Dutse metropolis. All the 379 respondents representing 100\% were of the view that provision of qualified English language teachers can improve the performance of students. Again, all the 379 respondents were of the view that use of proper and appropriate methods of teaching can improve the performance of students in English language in secondary schools of Dutse metropolis. 309 respondents representing $82 \%$ were of the view that provision of language laboratory for teaching English language can improve the performance secondary school students in Dutse metropolis while 70 respondents representing $18 \%$ were against this view. 355 respondents representing 94\% were of the view that listening to English language 
programme via television and other means improve the performance of students in English language in Dutse metropolis while 24 respondents representing $6 \%$ were against this view. Finally, 304 respondents representing $80 \%$ were of the view that organizing and participation in debates by students can improve their performance in English language in secondary schools of Dutse metropolis while 75 respondents were against this view.

Therefore, it is clear that provision of instructional materials, qualified teachers, using proper method of teaching, availability of language laboratory, listening to English language programme and participation in debates by students prove the performance of students in English language and even other subjects.

\section{Discussion of Results}

The discussion of findings is presented hereunder according to research questions of the study.

\section{Research Question One}

The results of the analysis of research question one showed that dominance of mother tongue, inadequate qualified teachers of English language, inadequate facilities and instructional media, teachers' attitude toward innovation and use of instructional media, negative attitude of students toward learning of English language and improper use of methods of teaching are some of the causes of poor performance in English language among senior secondary schools in Dutse metropolis of Jigawa state.

The findings of this study tally with the findings of Usman, (2012), Fema, (2003), Adedokun, (2011), Roger, (1981), Sa'ad, (2007), Mohammed, (1998), Abdullahi, (2003), Ya'u, (1993) who were of the view that the dominance of mother tongue or local language, inadequate qualified teachers of English language, inadequate facilities and instructional media, teachers' attitude toward innovation and use of instructional media, negative attitude of students toward the learning of English language and improper use of method of teaching are some causes of poor performance in English language among secondary school students of Dutse metropolis of Jigawa state.

\section{Research Question Two}

The results of the analysis of research question two showed that availability of instructional media or materials, availability of qualified of English language teachers, proper use of teaching methods, availability of language laboratory, listening of English language programmes and students' participation in debates can help to improve the performance of senior secondary school students in English language and even other subjects in Dutse metropolis of Jigawa state.

The findings of this study tally with the findings of Udumah, (1987), Abdullahi, (2003), Sa'ad, (2007), Abdulganiyyu, (2010) and Usman, (2012) who were of the view that provision of enough and relevant instructional media/materials and qualified teachers of English language improve the performance of secondary school students in Dutse metropolis of Jigawa state.

The findings also tally with findings of Udumah, (1987) stated that students should be taught correct pronunciation in English language to minimize the effect of first language on the second (English language) and students should be encouraged to communicate in English language in and outside the classroom and facilities like language laboratory should be provided.

\section{Conclusions}

Based on the findings of this study, the following conclusions were made:

That the causes of poor performance in English language among senior secondary school students in Dutse metropolis of Jigawa state include dominance of mother tongue, inadequate teachers of English language, inadequate facilities and instructional media/materials, teachers' attitude toward innovation and use of instructional media, negative attitude of students toward learning English language and improper use of methods of teaching by teachers.

That provision and appropriate use of instructional media/materials, provision of qualified teachers of English language, use of proper methods of teaching, provision of language laboratory, listening to English language programmes and engaging students in debating activity can improve the performance of senior secondary school students in English language in Dutse metropolis of Jigawa state.

\section{Recommendations}

Qualified teachers of English language should always be employed to handle the course in all the senior secondary schools of Dutse metropolis of Jigawa state.

Adequate instructional media/materials should provided where not available improvisation should be adopted by the English teachers of senior secondary schools of Dutse metropolis of Jigawa state.

Proper supervision by both the administrations of the senior secondary schools of Dutse metropolis and Jigawa state ministry of education should be conducted to make sure teachers of English language are actually doing what they are expected to do. 
Inter-senior secondary school competition in area of debate and other academic activities should be organized by the state ministry of education at least twice a year. This will definitely improve the spoken aspect of English language among the senior secondary school students in Dutse metropolis of Jigawa state.

There should be provision of at least one language laboratory for English language teaching. This will improve the performance of students in senior secondary schools of Jigawa state.

\section{References}

[1]. Abdullahi, M. (2003). The attitude of Science Teachers in the Use of Instructional Media. In Kano Journal of Education. 2 (1): pp 30-33.

[2]. Adedokun, A. O. (2011). Notes on Language Linguistics (Phonetics and Phonology) and English Language Method. Ibadan: Fab Publishers.

[3]. Danladi, S. S. (2013). "Language Policy: Nigeria and the Role of English Language in the $21^{\text {st }}$ Century". European Scientific Journal: 9 (17) pp. 1-21.

[4]. Daily Trust, Wednesday, $25^{\text {th }}$ August, 2010.

[5]. Eguiridu, C. Daily Trust, Thursday $21^{\text {st }}$ August, 2014

[6]. Fema, B. M. (2003). Problem of Teaching English Language in NCE Programme. In Azare Journal of Education. 4 (1): pp. 107112

[7]. Kolo, A. I. (1992). Essential of Research in Education (A Handbook for Students and Beginning Reseachers in Education). Lagos: Text and Leisure Publishers.

[8]. Mohammad, A. Y. (2002). Promoting Children Language and Communication Development For Successful Democracy and National Development. A Paper Presented at the School Of Education National Conference, Federal College of Education, Kano.

[9]. Oluwole, D. A. (2008). "The Impact of Mother Tongue on Students' Achievement in English Language in Junior Secondary Certificate Examination in Western Nigeria". Journal of Social Sciences. 17 (1): 41 -49.

[10]. Odumah, A. E. (1987). Nigerian English. Zaria: Ahmadu Bello University Press.

[11]. Osuala, E. O. (1985). Introduction to Reseach Methodology. Onitsha: African Fab Publishers.

[12]. Roger, B. (1981). An Introduction to Applied Linguistics, Approaches/Methods in Language Teaching. Oxford: Oxford University Press.

[13]. Sa'ad, T. U. (2007). The Impact of Domestic Responsibilities on the Academic achievement Of Married Women in Tertiary Institutions of Bauchi state. Unpublished Med Thesis. Bayero University, Kano.

[14]. Ya'u, M. Z. (1993). A Study of the Implementation of the National Islamic Studies Curriculum in Senior Secondary Schools of Bauchi State. Unpublished Med Thesis. Bayero University, Kano 